\title{
Changes in Teacher Training within the TPACK Model Framework: A Systematic Review
}

\author{
Javier Rodríguez Moreno $₫$, Miriam Agreda Montoro *®i and Ana María Ortiz Colón $₫$ \\ Department of Pedagogy, University of Jaén, 23071 Jaén, Spain; jrmoreno@ujaen.es (J.R.M.); \\ aortiz@ujaen.es (A.M.O.C.) \\ * Correspondence: magreda@ujaen.es
}

Received: 7 March 2019; Accepted: 25 March 2019; Published: 28 March 2019

check for updates

\begin{abstract}
The TPACK model represents a high-impact advance in teacher training regarding their technological, pedagogical and content knowledge. This research presents an analysis of several publications in international databases that address the matter of the TPACK model. Accordingly, a review of the scientific literature applying the documentation as a systematization method was performed. The present study analyses 37 contributions, published between 2014 and 2017, indexed in the Web of Science (WOS) and Scopus databases, with TPACK and TPCK as the applied descriptors. Thus, the documentary analysis was based on four different criteria: public, topic, main results, and methodological design. Results show that all the reviewed publications are mainly focused on studies of basic and higher education where case studies, quantitative empirical studies, and mixed studies are predominant. Consequently, regarding the studies analyzed, there is a lack of longitudinal studies showing the teachers' actions when applying TPACK in their daily practice.
\end{abstract}

Keywords: TPACK; TPCK; science education; teacher training; ICT

\section{Introduction}

The research shows the importance of the TPACK model designed by Mishra and Koehler (2006), regarding the integration of pedagogical, technological and content knowledge when teachers introduce technology in a classroom context. Furthermore, it is necessary to know its interaction with other kinds of knowledge, such as pedagogical content knowledge (PCK), technological content knowledge (TCK), and technological pedagogical knowledge (TPK).

The relevance of this study lies in the integration of technology by teachers as part of their teaching practice. For this reason, teacher training in information and communication technology (ICT) needs to investigate the theoretical foundations guiding their application and use in the classroom, both at a disciplinary and at a pedagogical level [1,2], together with technological knowledge on how ICT work in its implementation [3].

The TPACK model distinguishes three basic dimensions of training and four intersections between them; the model identifies seven dimensions in total, along with the differentiated context of training.

- Content Knowledge (CK): it refers to the content knowledge that the teacher possesses in specific matters or areas that must be taught to the students, including concepts, theories, facts and procedures in the area.

- Pedagogical Knowledge (PK): it refers to the knowledge possessed by the teacher regarding pedagogical activities, processes, practices, teaching and learning methods used in the teaching-learning process, and how they relate to the educational goals. PK also includes the knowledge of techniques and methods that can be used in the classroom, and strategies to evaluate students. 
- Technological Knowledge (TK): it refers to the teacher's knowledge regarding different technologies in order to develop the teaching practice. It includes, for instance, knowledge of operating systems and hardware, how to install programs, and how to create documents. It is also important to learn and to adapt to upcoming new technologies.

- Pedagogical Content Knowledge (PCK): it refers to the didactic knowledge about a content area, which implies facilitating the student's learning in that area. This dimension also implies knowing what teaching approaches and strategies are better adapted to the content and how the different elements of content can be worked out for effective teaching.

- Technological Content Knowledge (TCK): this includes the knowledge of how to represent specific concepts with technology, which means the way technology and discipline are reciprocally linked. Teachers need to know the way the contents in their respective areas are being affected by the application of technologies.

- Technological Pedagogical Knowledge (TPK): refers to the knowledge of general pedagogical strategies that can be performed thanks to technology. This includes knowing the appropriate tools for a specific task, the abilities to choose the right tool based on the efficiency or adequacy to the task, and the ability to apply pedagogical strategies when using technologies.

- Technological Pedagogical Content Knowledge (TPACK): refers to a teacher's knowledge on how to develop specific didactic strategies on different matters using ICT in order to facilitate learning. Therefore, it is a form of knowledge that goes beyond these three components (content, pedagogy, and technology) TPACK includes, for example, the knowledge of pedagogical strategies that allow the effective use of technologies to teach the content of the discipline, and the knowledge of the aspects that make the content easy or difficult to learn, and how technology can help with some of the problems that students face.

In this vein, the experiences developed during the teacher's initial training stand out [4-9], as in different disciplinary contexts and educational levels.

There are many studies developed following the model detailed here [10], that try to clarify all its components. Among them, all the studies developed in [11], regarding the components included in the model, stand out; the studies carried out in [12], focused on the teacher's initial training, are worth mentioning; and also the non-experimental quantitative study conducted in [13] in 12 different pre-school and primary education centers. On the other hand, [14] created a tool, following the TPACK model, to determine future science teachers' beliefs on their self-efficacy. [15] and [16] created some instruments considering the TPACK dimensions. Other studies make an approach to the development of TPACK abilities [17] and to the attitudes towards ICT and their relation with TPACK $[18,19]$.

Taking the previous ideas as a reference, we present a documentary analysis developed around the TPACK model, after analyzing the studies, published in the Web of Science and Scopus databases from 2014 to 2017, on investigations conducted on technological, pedagogical, and content knowledge. Therefore, the objective of this study has been to provide a current overview of the implementation of the TPACK model in the educational field.

\section{Methodology}

The methodology of the study was based on the documentary analysis, using documentation as a data gathering method [20]. Accordingly, the tasks of the study aim to determine to the public, to whom the research is directed, the main topics defined and the research methodologies used. The most relevant results obtained from the studies are shown.

We looked for empirical studies on the TPACK model. The articles found in databases such as the Web of Science and Scopus were considered for the study. The preliminary searching strategy applies the option "topic" in the "Web of Science (WOS)" database, while the Scopus database uses the option "article, title, summary and keyword." The timespan was established from the study of [21], from 2014 
to 2017. The total amount of works considered was 37, and the descriptors applied TPACK and TPCK, of which a high percentage of the publications in indexed scientific journals, in both databases, were reiterated. The study was designed following the structure and recommendations of other systematic reviews [22-25] regarding databases, searching strategies, limits, and filtered documents presented in Table 1.

Table 1. Preliminary analysis of the document search.

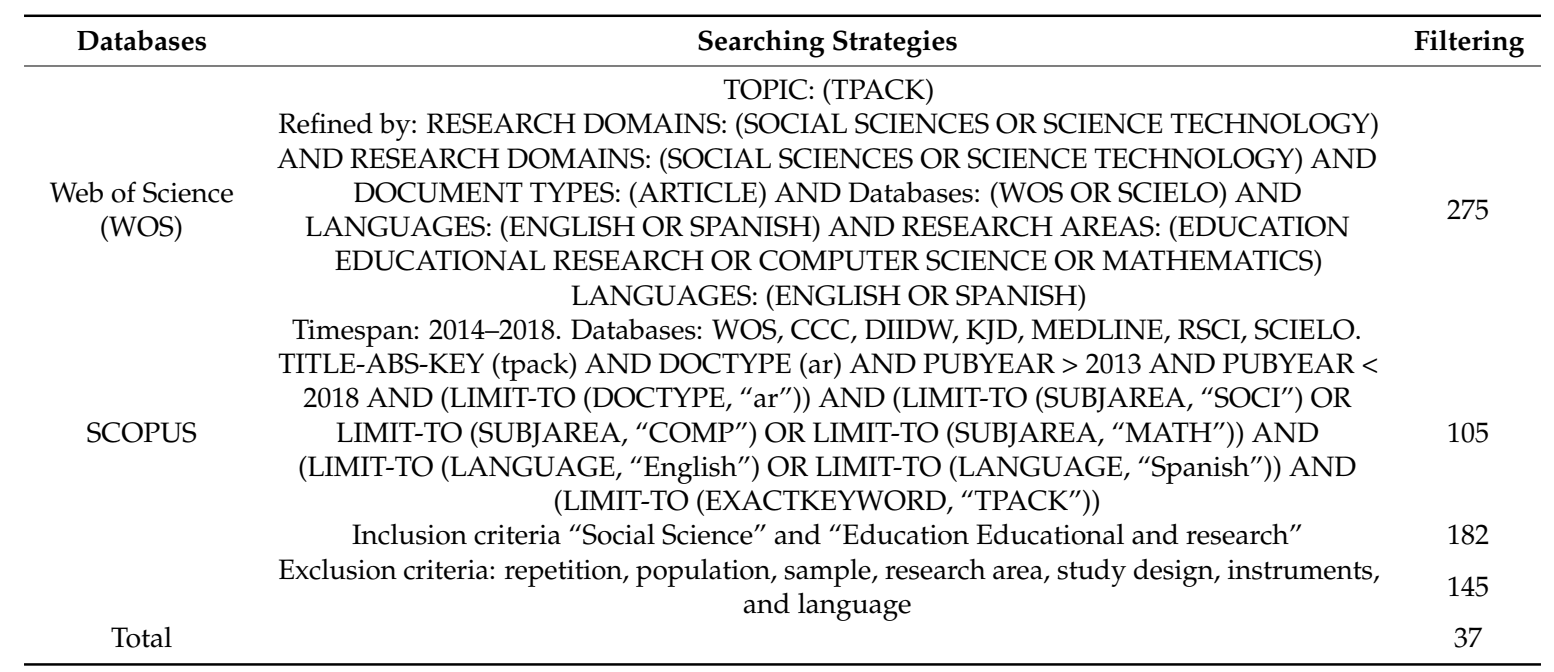

\section{Procedure}

The general selection criteria refer to articles in peer-reviewed journals with populations regarding educational contexts and quantitative, qualitative, or mixed methodological design. The studies co-authorship has been another aspect that has been taken into account regarding the collaboration degree (CD) in each document [26]. A global value of the CD of 0.95 (Table 2) was obtained during the 2014-2017 timespan, which indicates a high number of authors within the records selected for the study, mostly in the Web of Science and, to a lesser extent, in Scopus [27].

Table 2. Collaboration degree (CD) in the documents.

\begin{tabular}{ccccc}
\hline Indexed From & Documents & $\mathbf{N}$ & $\mathbf{f 1}$ & $\mathbf{C D}$ \\
\hline 2017 & 9 & 31 & 0 & 1.00 \\
2016 & 12 & 31 & 1 & 0.97 \\
2015 & 4 & 9 & 1 & 0.89 \\
2014 & 12 & 28 & 3 & 0.89 \\
& 37 & 99 & & \\
Total & & 99 & 5 & 0.95 \\
\hline
\end{tabular}

With regard to data extraction, the number of records in their initial phase was 380; 275 of them were obtained from the Web of Science and 105 from Scopus, 99 of them were repeated, and only 6 records appeared in Scopus, filtering a total of 182 records, as shown in Figure 1. A total of 145 records were excluded, all of them following a filtering procedure regarding population, sample, research area, study design, instruments, and language. 


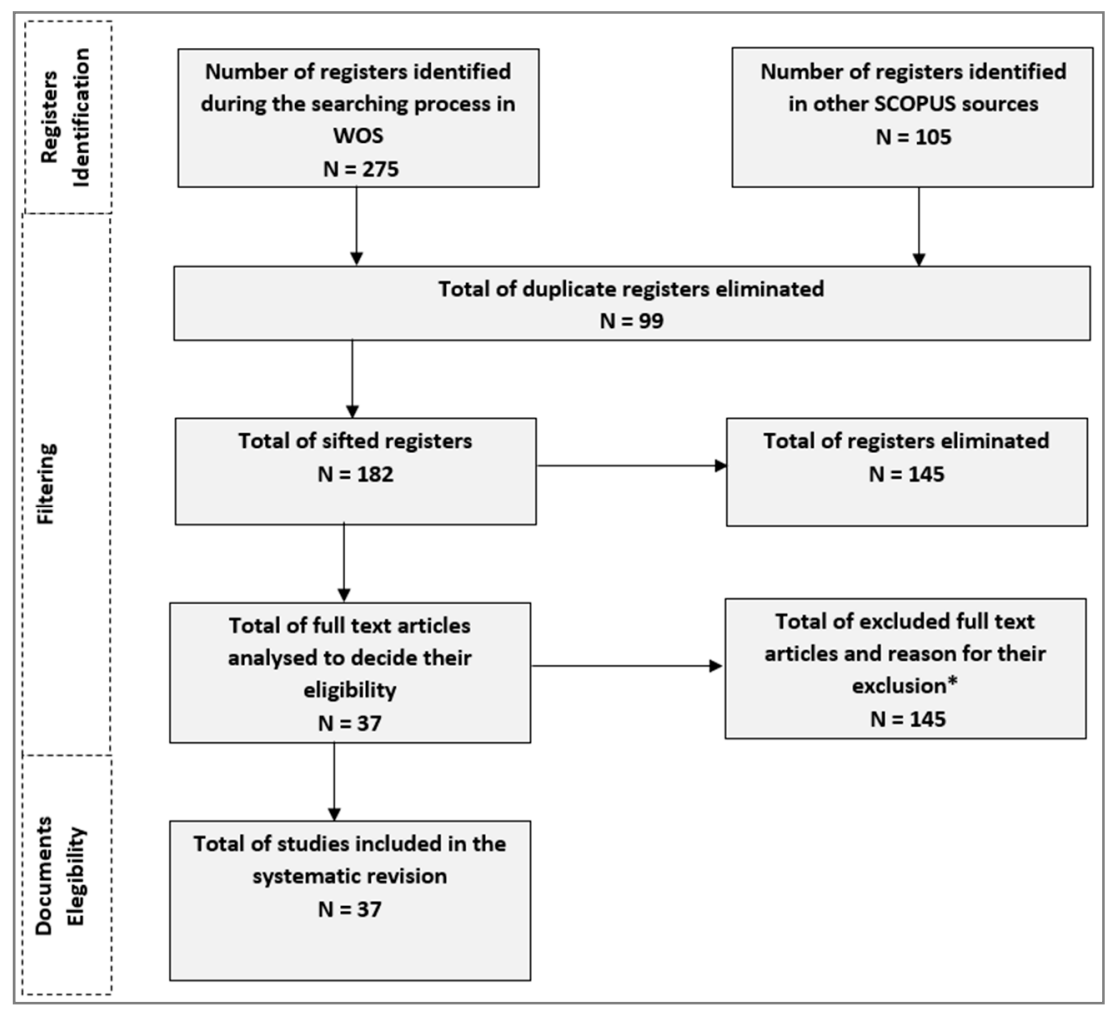

Figure 1. Information flow diagram.

Figure 2 has allowed us to check the evolution of the studies about TPACK and TPCK in the last years, from 2014 to 2017, distributed in the two selected databases.

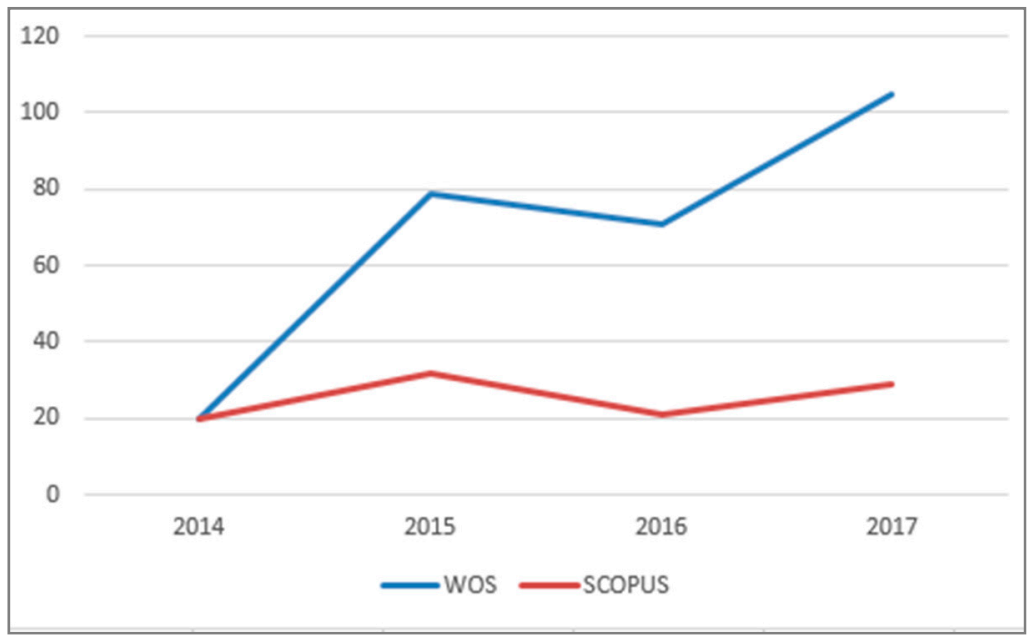

Figure 2. Distribution of publications from 2014 to 2017.

A total of 37 complete articles, which constitutes the population of the study, were evaluated for their inclusion in the final review, after being checked by two external revisers who confirmed the definitive extraction and selection based on the inclusion and exclusion criteria (see Table 3). 
Table 3. List of evaluated articles composing the final review.

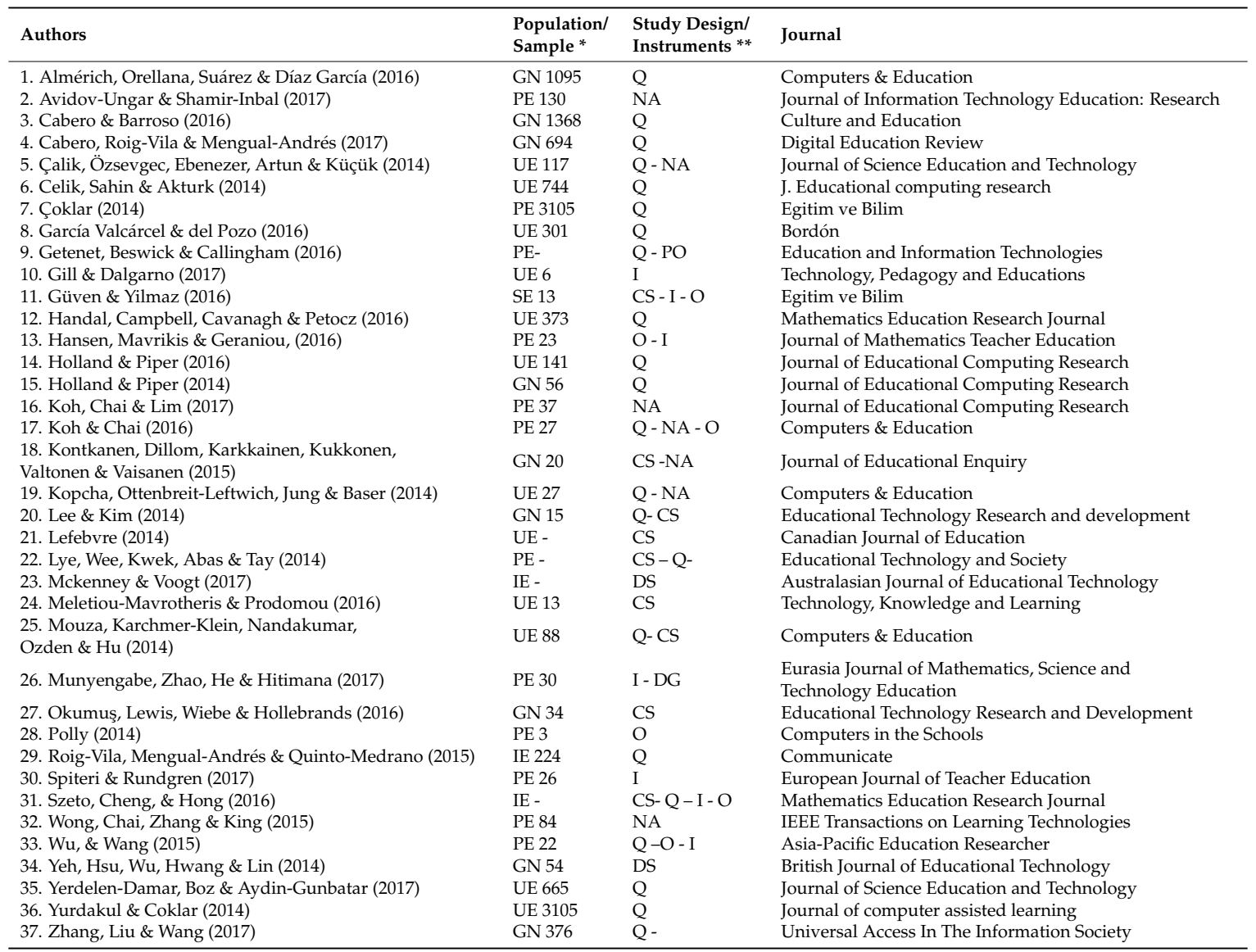

* IE: pre-school/infant education; PE: primary education; SE: secondary education; UE: university education; GN: general; ${ }^{* *}$ CS: case studies; I: interviews; O: observation; PO: participant observation; Q: questionnaire; DG: discussion group; NA: narrative analysis; DS: delphi study.

Regarding the documentary analysis, the developed procedure was based on four different criteria: public, topic, main results, and methodological design [9]. All of them facilitate the categorization and synthesis of the gathered information with "TPACK and TPCK" in the Web of Science and Scopus databases, establishing the following categories and subcategories:

- Public: pre-school education, primary education, secondary education, higher education, trainers' training, and general.

- Topic: ICT integration, attitudes towards ICT, professional development of teaching; TPACK conceptual framework.

- Main results: the effects and consequences of the outcomes.

- Methodological design: empirical with qualitative techniques, empirical with quantitative techniques, empirical with mixed techniques.

\section{Results}

An in-depth analysis of all the studies showed that all of them are referred to TPACK (100\%), 14 of them deepen in ICT integration in the TPACK framework; 10 of them are focused on the professional development of teachers (in digital competence); 9 of them are focused on the TPACK theoretical framework and 4 of them on the attitudes towards ICT and their relation with the TPACK model. In all the studies, the techniques and instruments used applied a quantitative, qualitative or mixed research methodology. The questionnaire was the most used instrument (19 studies), followed by case studies (8 studies), and narrative analysis (7 studies), of qualitative typology. Regarding the 
degree of co-authorship, 32 of the studies had between two and five authors, and only five studies were conducted by just one author. This review includes data from, approximately, 13,016 individuals, with a variability of sample sizes ranging from3 to 3105 participants depending on whether the design was quantitative, qualitative, or mixed. Studies were mostly carried out in English $(89.12 \%)$, and 4 of them in Spanish (10.8\%). The results from the documentary analysis are structured around the following criteria:

\subsection{Public}

Among the reviewed publications, 35.3\% of them used research samples referred to primary education students, followed by higher education students (32.4\%). On the other hand, $13.5 \%$ of the publications are of a general nature and addressed to the general public; $10.8 \%$ are addressed to teacher training; $5.4 \%$ of them are pre-school education oriented; $2.7 \%$ of the publications correspond to secondary education (see Table 4).

Table 4. Distribution of publications according to the public.

\begin{tabular}{|c|c|}
\hline Public & Publications \\
\hline $\begin{array}{l}\text { Pre-school } \\
\text { education [2] }\end{array}$ & (Szeto, Cheng, Hong 2016; Roig-Vila, Mengual-Andrés \& Quinto-Medrano 2015). \\
\hline $\begin{array}{l}\text { Primary } \\
\text { education [13] }\end{array}$ & $\begin{array}{l}\text { (Avidov-Ungar \& Shamir-Inbal 2017; Koh, Chai \& Lim 2017; Koh, \& Chai 2016; Mckenney \& Voogt } \\
\text { 2017; Munyengabe, Zhao, Éi \& Hitimana 2017; Spiteri \& Rundgren 2017; Getenet, Beswick \& } \\
\text { Callingham 2016; Hansen, Mavrikis \& Geraniou 2016; Wong, Chai, Zhang \& King 2015; Wu, \& Wang } \\
\text { 2015; Çoklar 2014, Lye, Wee, Kwek, Abas \& Tay 2014; Polly 2014). }\end{array}$ \\
\hline $\begin{array}{l}\text { Secondary } \\
\text { education }[1]\end{array}$ & (Güven \& Yilmaz 2016). \\
\hline $\begin{array}{l}\text { Higher } \\
\text { education [12] }\end{array}$ & $\begin{array}{l}\text { (García Valcárcel \& Del Pozo 2016; Gill \& Dalgarno 2017; Yerdelen-Damar, Boz \& Aydin-Gunbatar } \\
\text { 2017; Holland \& Piper 2016; Meletiou-Mavrotheris \& Prodomou 2016; Handal, Campbell, Cavanagh \& } \\
\text { Petocz 2016; Çalik, Özsevgec, Ebenezer, Artun \& Küçük 2014; Celik, Sahin, \& Akturk 2014; Kopcha, } \\
\text { Ottenbreit-Leftwich, Jung \& Baser 2014; Lee \& Kim 2014; Mouza, Karchmer-Klein, Nandakumar, } \\
\text { Ozden \& Hu 2014; Yurdakul \& Çoklar 2014). }\end{array}$ \\
\hline $\begin{array}{l}\text { Trainers } \\
\text { training [4] }\end{array}$ & $\begin{array}{l}\text { (Zhang, Liu \& Wang 2017; Okumuş, Lewis, Wiebe \& Hollebrands 2016; Kontkanen, Dillom, } \\
\text { Karkkainen, Kukkonen, Valtonen \& Vaisanen 2015; Yeh, Hsu, Wu, Hwang \& Lin 2014). }\end{array}$ \\
\hline General [5] & $\begin{array}{l}\text { (Almerich, Orellana, Suarez, Diaz Garcia 2016; Cabero, Roig-Vila y Mengual-Andres 2017; Cabero y } \\
\text { Barroso 2016; Holland \& Piper 2014; Lefebvre 2014). }\end{array}$ \\
\hline
\end{tabular}

\subsection{Topic}

Regarding the keywords and the general objectives (see Table 5), 37.8\% of the articles deal with technology integration in the TPACK model framework. $27.02 \%$ of the articles refer to the professional development of teachers in digital competence, either in their initial or continuous training, in university and non-university contexts. On the other hand, 10.8\% focus on the students' attitudes towards ICT. Lastly, $24.3 \%$ of the articles refer to the TPACK theoretical framework.

Table 5. Distribution of publications according to the topic.

\begin{tabular}{ll}
\hline Topic & Publications \\
\hline & (Güven \& Yilmaz 2016; Munyengabe, Zhao, Éi \& Hitimana 2017; Hansen, Mavrikis \& Geraniou 2016; \\
& $\begin{array}{l}\text { Holland \& Piper 2016; Okumuş, Lewis, Wiebe \& Hollebrands 2016; Szeto, Cheng, Hong 2016; Kontkanen, } \\
\text { Dillom, Karkkainen, Kukkonen, Valtonen \& Vaisanen 2015; Roig-Vila, Mengual-Andrés \& } \\
\text { Quinto-Medrano 2015; Çoklar 2014; Lee \& Kim 2014; Lye, Wee, Kwek, Abas \& Tay 2014; Mouza, } \\
\text { Karchmer-Klein, Nandakumar, Ozden \& Hu 2014; Polly 2014; Yurdakul \& Çoklar 2014). }\end{array}$ \\
& (Avidov-Ungar \& Shamir-Inbal 2017; Yerdelen-Damar, Boz \& Aydin-Gunbatar 2017; Holland \& Piper \\
ICT attitudes [4] & 2014; Koh, \& Chai 2016). \\
Professional & (Cabero, Roig-Vila y Mengual-Andrés 2017; Gill \& Dalgarno 2017; Koh, Chai \& Lim 2017; Mckenney \& \\
development of & Voogt 2017; Spiteri \& Rundgren 2017; Zhang, Liu \& Wang 2017; Almérich, Orellana, Suárez \& Díaz García \\
teachers (digital & 2016; García Valcárcel \& del Pozo 2016; Getenet, Beswick \& Callingham 2016; Meletiou-Mavrotheris \& \\
competence) [10] & $\begin{array}{l}\text { Prodomou 2016). } \\
\text { (Cabero \& Barroso 2016; Handal, Campbell, Cavanagh \& Petocz 2016; Wong, Chai, Zhang \& King 2015; }\end{array}$ \\
TPACK conceptual \\
framework [9]
\end{tabular}$\quad \begin{aligned} & \text { Wu, \& Wang 2015; Çalik, Özsevgec, Ebenezer, Artun \& Küçük 2014; Celik, Sahin, \& Akturk 2014; Kopcha, } \\
& \text { Ottenbreit-Leftwich, Jung \& Baser 2014; Lefebvre 2014; Yeh, Hsu, Wu, Hwang \& Lin 2014). }\end{aligned}$




\subsection{Main Results}

The third criterion allows us to value the contributions of every selected investigation. The convergence between ICT and TPACK is presented as positive in $51.10 \%$ of the analyzed texts. More specifically, $34.89 \%$ of the texts reveal the importance of acquiring abilities in the TPACK framework, the achievement of objectives, the development of practical goals, task performance, and problem-solving. $16.21 \%$ of the texts highlight the technological competence and, more specifically, the digital competence; and also $16.27 \%$ remarks the improvement of the learning results in the TPACK context. Other studies consider the TPACK model as a reference with regards to diagnosis in professional development $(27.02 \%)$, and there were very few studies on the obstacles that the use of technology poses in educational contexts $(4.76 \%$ ) (see Table 6$)$.

Table 6. Distribution of publications according to the main results.

\begin{tabular}{|c|c|}
\hline Results & Publications \\
\hline TPACK abilities [13] & $\begin{array}{l}\text { (Almérich, Orellana, Suárez \& Díaz García 2016; Avidov-Ungar \& Shamir-Inbal 2017; Gill \& } \\
\text { Dalgarno 2017; Mckenney \& Voogt 2017; Munyengabe, Zhao, Éi \& Hitimana 2017; } \\
\text { García-Valcárcel \& Martín del Pozo 2016; Okumuş, Lewis, Wiebe \& Hollebrands 2016; Çalik, } \\
\text { Özsevgec, Ebenezer, Artun \& Küçük 2014; Celik, Sahin, \& Akturk 2014; Holland \& Piper 2014; } \\
\text { Kopcha, Ottenbreit-Leftwich, Jung \& Baser 2014; Lee \& Kim 2014; Yurdakul \& Çoklar 2014). }\end{array}$ \\
\hline $\begin{array}{l}\text { Technological } \\
\text { competence-Digital } \\
\text { competence [6] }\end{array}$ & $\begin{array}{l}\text { (Spiteri \& Rundgren 2017; Yerdelen-Damar, Boz \& Aydin-Gunbatar 2017; Zhang, Liu \& Wang 2017; } \\
\text { Getenet, Beswick \& Callingham 2016; Orellana, Suárez \& Díaz García 2016; Çoklar 2014). }\end{array}$ \\
\hline Learning results [6] & $\begin{array}{l}\text { (Güven \& Yilmaz 2016; Koh, Chai \& Ling 2017; Handal, Campbell, Cavanagh \& Petocz 2016; } \\
\text { Meletiou-Mavrotheris \& Prodomou 2016; Wong, Chai, Zhang \& King 2015; Mouza, } \\
\text { Karchmer-Klein, Nandakumar, Ozden \& Hu 2014). }\end{array}$ \\
\hline $\begin{array}{l}\text { Professional development } \\
\text { of teachers [10] }\end{array}$ & $\begin{array}{l}\text { (Cabero, Roig-Vila y Mengual-Andrés 2017; Cabero \& Barroso 2016; Holland \& Piper 2016; Szeto, } \\
\text { Cheng, Hong 2016; Kontkanen, Dillom, Karkkainen, Kukkonen, Valtonen \& Vaisanen 2015; } \\
\text { Roig-Vila, Mengual-Andrés \& Quinto-Medrano 2015; Koh, \& Chai 2016; Lefebvre 2014; Polly 2014; } \\
\text { Yeh, Hsu, Wu, Hwang \& Lin 2014). }\end{array}$ \\
\hline Obstacles [2] & (Hansen, Mavrikis \& Geraniou 2016; Lye, Wee, Kwek, Abas \& Tay 2014). \\
\hline
\end{tabular}

\subsection{Methodological Design}

Regarding the methodological design (see Table 7), the most used systematic process is the substantiation through empirical studies with quantitative techniques (43.24\%), followed by qualitative studies $(40.24 \%)$, and mixed studies (16.21\%). In the same way, the tools used on empirical studies are surveys and questionnaires, in $85 \%$ of the cases. To a lesser extent, delphi and instrument validation studies appear as well. On the other hand, the size of the samples is remarkably variable; this means that there is no common magnitude for sampling between different studies.

Table 7. Distribution of publications according to their methodological design.

\begin{tabular}{ll}
\hline Methodological Design & Publications \\
\hline & (Avidov-Ungar \& Shamir-Inbal 2017; Gill \& Dalgarno 2017; Güven \& Yilmaz 2016; Munyengabe, \\
& Zhao, Éi \& Hitimana 2017; Spiteri \& Rundgren 2017; Hansen, Mavrikis \& Geraniou 2016; \\
Empirical with qualitative & -Mavrotheris \& Prodomou 2016; Okumuş, Lewis, Wiebe \& Hollebrands 2016; Szeto, Cheng, \\
techniques [15] & Hong 2016; Kontkanen, Dillom, Karkkainen, Kukkonen, Valtonen \& Vaisanen 2015; Wong, Chai, \\
& Zhang \& King 2015; Kopcha, Ottenbreit-Leftwich, Jung \& Baser 2014; Lee \& Kim 2014; Lefebvre \\
& 2014; Polly 2014). \\
& (Cabero, Roig-Vila y Mengual-Andrés 2017; Mckenney \& Voogt 2017; Yerdelen-Damar, Boz \& \\
& Aydin-Gunbatar 2017; Zhang, Liu \& Wang 2017; Almérich, Orellana, Suárez, Díaz García 2016; \\
& Cabero \& Barroso 2016; García Valcárcel \& del Pozo 2016; Holland \& Piper 2016; Handal, \\
& Campbell, Cavanagh \& Petocz 2016; Roig-Vila, Mengual-Andrés \& Quinto-Medrano 2015; Celik, \\
Empirical with quantitative & Sahin, \& Akturk 2014; Çoklar 2014; Holland \& Piper 2014; Lye, Wee, Kwek, Abas \& Tay 2014; \\
techniques [16] & Yeh, Hsu, Wu, Hwang \& Lin 2014; Yurdakul \& Çoklar 2014). \\
& (Çalik, Özsevgec, Ebenezer, Artun \& Küçük 2014; Getenet, Beswick \& Callingham 2016; Koh, \\
& Chai \& Lim 2017; Koh, \& Chai 2016; Wu \& Wang 2015; Mouza, Karchmer-Klein, Nandakumar, \\
Empirical with mixed & Ozden \& Hu 2014). \\
\hline
\end{tabular}




\section{Discussion}

The empirical studies analyzed maintain the TPACK model as an efficient and reliable framework to guide the research about the integration of technology in the classroom [28]. The inclusion of the TPACK model in the curricula, related to teacher training, is established as a fundamental axis to give the possibility of experimenting with ICT, within specific content areas [29]. Currently, research in this field of study requires a deep exploration and theoretical argumentation to address the complexity inherent in the integration of technology in teaching practice [30]. Technology has to be understood as a methodical and holistic process inserted in the initial teacher training, starting from a collaborative learning, active participation, and through the design of materials as a final product that leads to significant learning processes [6,31].

Those dimensions cannot be conceived separately, which highlights the teacher's role when it comes to planning didactic activities. Nowadays, this assumption is not only specified in several studies [21], but it has also been verified, thanks to the performed documentary review, that the TPACK model can promote the technological abilities and the pedagogical and disciplinary content in most of the developed researches. There is a need to expand the research on conceptual studies by applying specific technologies in certain areas of knowledge [32] and their specific content.

\section{Conclusions}

This study aimed to understand the evolution of the TPACK model among the scientific community starting a decade ago, when [10] considered introducing technology, along with pedagogy and the content knowledge of teachers in classrooms. We have also been able to confirm that both personal and contextual factors have a significant impact on the subsets of the analyzed competences. It is, thus, evident within the TPACK conceptual framework that the integration of ICT correlates positively with the analyzed work on the TPACK model.

A total of 37 articles from scientific journals from Scopus and Web of Science were analyzed. This review reflects the current situation (from 2014 to 2017) of teachers' training regarding their technological, pedagogical, and content knowledge. It is considered that these basic dimensions, as well as the intersections they generate, confirm a solid model that allows obtaining a good diagnosis of teachers both in their initial and permanent training. This panorama, in relation to the public criteria, is shaped by studies ( 25 publications) where the predominant sample consists of students of higher and primary education. Regarding the investigations carried out in the context of primary and higher education, being the latter linked to teachers in training at universities, they confirm the advances in technology in primary education classrooms in the future due to the teachers' acquisition of the technological, pedagogical, and content competence during their initial training. On the other hand, the investigations of general nature and with trainers carried out within the framework of the TPACK model (9 publications) reaffirm these conclusions.

As for the topics, 14 publications refer to the integration of technology in the framework of the TPACK model; 10 refer to the professional development of teachers in digital competence, either in their initial or continuous training, in university and non-university contexts; 9 refer to the TPACK conceptual framework, followed by 4 documents referring to the attitudes of students in the technological context of the TPACK.

Regarding the results criteria, 19 publications reiterate the convergence between ICT and TPACK in a positive way within the analyzed texts, 6 of them emphasize the technological competence and, specifically, the digital competence also; 6 documents highlight the improvement of the learning results in the TPACK context. Lastly, there are 10 documents that highlight the professional development of teachers in the TPACK framework. Finally, the predominant methodological design refers to empirical studies with quantitative techniques (16 publications), followed by qualitative studies (15), along with mixed studies (6), in accordance with the established categorization and synthesis of information [9] between "TPACK" and "TPCK". 
On the other hand, there is a high level of co-authorship in the degree of collaboration of the studies, with a collaboration degree of 0.95 , due to the nature of the research problem and the financial support, a result of subsidized research projects, as well as a high visibility and quotation of the selected studies [26]. As limitations, we can mention the lack of longitudinal empirical studies and studies in pre-school and secondary education, being the majority of the target students of higher and primary education. Carrying out these type of studies would have a great potential for determining the consequences in the educational field and developing improvement proposals. In addition, it is worth mentioning the variability observed in the study samples, as there were large differences in the typology of the studies analyzed.

Author Contributions: Conceptualization, J.R.M.; collecting data and research methodology, A.M.O.C. and J.R.M..; validation and formal analysis, AM.O.C. and M.A.M.; investigation, J.R.M..; resources, J.R.M..; data curation, M.A.M.; writing—original draft preparation, J.R.M.; A.M.O.C and M.A.M.; writing—review, J.R.M.; A.M.O.C and M.A.M; visualization, J.R.M and A.M.O.C; supervision, M.A.M.; project administration, A.M.O.C.

Funding: This research received no external funding.

Acknowledgments: We are grateful to the journal editors and three anonymous reviewers for their time and helpful comments to improve the paper.

Conflicts of Interest: The authors declare no conflict of interest.

\section{References}

1. Shulman, L.S. Those who understand: Knowledge growth in teaching. Educ. Res. 1986, 15, 4-14. [CrossRef]

2. Shulman, L.S. Conocimiento y Enseñanza: Fundamentos de una nueva reforma. Profesorado 2005, 9, 2.

3. Cabero, J. La Formación del Profesorado en TIC: Modelo TPACK. Conocimiento Tecnológico Pedagógico y de Contenido; University of Sevilla: Sevilla, Spain, 2014. Available online: https://www.academia.edu/ 8021740/La_formaci\%C3\%B3n_dle_profesorado_en_TIC_Modelo_TPACK_Conocimiento_tecnol\%C3\% B3gico_pedag\%C3\%B3gico_y_de_contenido_ (accessed on 3 October 2018).

4. Jang, S.J.; Chen, K.C. From PCK to TPACK: Developing a Transformative Model for Pre-Service Science Teachers. J. Sci. Educ. Technol. 2010, 19, 553-564. [CrossRef]

5. Maeng, J.L.; Mulvey, B.K.; Smetana, L.K.; Bell, R.L. Preservice Teachers TPACK: Using Technology to Support Inquiry Instruction. J. Sci. Educ. Technol. 2013, 22, 838-857. [CrossRef]

6. Mouza, C.; Karchmer-Klein, R.; Nandakumar, R.; Yilmaz, S. Investigating the impact of an integrated approach to the development of preservice teachers technological pedagogical content knowledge (TPACK). Comput. Educ. 2014, 71, 206-221. [CrossRef]

7. Pamuk, S. Understanding preservice teachers' technology use through TPACK framework. J. Comput. Assist. Learn. 2012, 28, 425-439. [CrossRef]

8. Srisawasdi, N. The Role of TPACK in Physics Classroom: Case Studies of Preservice Physics Teachers. Procedia-Soc. Behav. Sci. 2012, 46, 3235-3243. [CrossRef]

9. Wollscheid, S.; Sjaastad, J.; Tømte, C. The impact of digital devices vs. Pen (cil) and paper on primary school students' writing skills-A research review. Comput. Educ. 2016, 95, 19-35. [CrossRef]

10. Mishra, P.; Koehler, J. Technological pedagogical content knowledge: A new framework for teacher knowledge. Teach. Coll. Rec. 2006, 108, 1017-1054. [CrossRef]

11. Cox, S.; Graham, C. Diagramming TPACK in practice: Using an elaborated model of the TPACK framework to analyze and depict teacher knowledge. TechTrends 2009, 53, 60-69. [CrossRef]

12. García-Valcárcel, A.; Martín del Pozo, M. ¿Se sienten preparados los graduados en maestro de primaria para afrontar la profesión docente? Bordón 2016, 68, 2. [CrossRef]

13. Roig, R.; Mengual, S.; Quinto, P. Primary Teachers' Technological, Pedagogical and Content Knowledge. Comunicar 2015, 45, 151-159. [CrossRef]

14. Bilici, S.; Yamak, H.; Kavak, N.; Guzey, S.S. Technological pedagogical content knowledge self-efficacy scale (TPACK-SeS) for preservice science teachers: Construction, validation and reliability. Eurasian J. Educ. Res. 2013, 52, 37-60. Available online: https:/ / eric.ed.gov/?id=EJ1060363 (accessed on 11 September 2018). 
15. Archambault, L.; Crippen, K. Examining TPACK among K-12 online distance educators in the United States. Contemp. Issues Technol. Teach. Educ. 2009, 9, 1. Available online: http://www.citejournal.org/vol9/iss1/ general/article2.cfm (accessed on 15 October 2018).

16. Jang, S.J.; Tsai, M.F. Exploring the TPACK of Taiwanese Elementary Mathematics and Science Teachers with Respect to Use of Interactive Whiteboards. Comput. Educ. 2012, 597, 327-338. [CrossRef]

17. Almerich, G.; Orellana, N.; Suárez-Rodríguez, J.; Díaz-García, I. Teachers' information and communication technology competences: A structural approach. Comput. Educ. 2016, 100, 110-125. [CrossRef]

18. Koh, J.L.; Chai, C.S.; Tsai, C.C. Examining the technological pedagogical content knowledge of Singapore preservice teachers with a large-scale survey. J. Comput. Assist. Learn. 2010, 26, 563-573. [CrossRef]

19. Avidov-Ungar, O.; Shamir-Inbal, T. ICT coordinators' TPACK-based leadership knowledge in their roles as agents of change. J. Inf. Technol. Educ. Res. 2017, 16, 169-188. Available online: http:/ /www.informingscience. org/Publications/3699 (accessed on 1 October 2018). [CrossRef]

20. Sampieri, R.; Collado, C.; Lucio, P. Metodología de la Investigación; McGraw-Hill: New York, NY, USA, 2014.

21. Castillejos-López, B.; Torres-Gastelú, C.A.; Lagunes-Domínguez, A. El enfoque del Conocimiento Tecnológico Pedagógico del Contenido (TPACK): Revisión del modelo. In Los Modelos Tecno-Educativos, Revolucionando el Aprendizaje del Siglo XXI; Gámez, I.E., Ed.; Lulú: Mexico, 2014; pp. 237-252. Available online: https: / / goo.gl/G8nTdk (accessed on 23 November 2018).

22. Torres-Toukoumidis, A.; Romero, L.M.; Pérez, A. Ludificación y sus posibilidades en el entorno de blended learning: Revisión documental, RIED. Rev. Iberoam. Educ. A Distancia 2018, 21, 95-111. [CrossRef]

23. Suarez-Manzano, S.; Ruiz-Ariza, A.; De La Torre-Cruz, M.; Martínez-López, E.J. Acute and chronic effect of physical activity on cognition and behaviour in young people with ADHD: A systematic review of intervention studies. Res. Dev. Disabil. 2018, 77, 12-23. [CrossRef]

24. Manca, S. ResearchGate and Academia.edu as networked socio-technical systems for scholarly communication: A literature review. Res. Learn. Technol. 2018, 26, 2008. Available online: https: / / dx.doi.org/10.25304/rlt.v26.2008 (accessed on 17 December 2018). [CrossRef]

25. Bírová, J.; Kružlík, P.; Kalimullin, A.M.; Sokolova, N.L.; Haroun, Z.; Králik, R.; Vasbieva, D.G. Mathematical and Statistical Bibliometric Indicators for Scholars in the Field of Romance Languages and Linguistics. Eurasia J. Math. Sci. Technol. Educ. 2018, 14, 1-15. Available online: https://doi.org/10.29333/ejmste/97826 (accessed on 18 December 2018).

26. Subramanyam, K. Bibliometric studies of research collaboration: A review. J. Inf. Sci. 1983, 6, 33-38. [CrossRef]

27. Jiménez-Fanjul, N. Producción Científica Internacional en Educación Matemática. Bibliometric Study (1983-2012); University of Cordoba: Córdoba, Spain, 9 May 2016. Available online: http://hdl.handle.net/10396/13759 (accessed on 18 December 2018).

28. Abbit, J.T. An investigation of the relationship between self-efficacy beliefs about technology integration and technological pedagogical content knowledge (TPACK) among preservice teachers. J. Digit. Learn. Teach. Educ. 2011, 27, 134-143. [CrossRef]

29. Voogt, J.; Fisser, P.; Roblin, N.P.; Tondeur, J.; van Braak, J. Technological pedagogical content knowledge-a review of the literature. J. Comput. Assist. Learn. 2013, 29, 109-121. [CrossRef]

30. Rahman, A.S.A.; Harun, R.N.S.R. Tesl Pre-Service Teachers' Tpack: A Review. Int. J. Acad. Res. Bus. Soc. Sci. 2018, 8, 795-804. [CrossRef]

31. Lee, C.J.; Kim, C. An implementation study of a TPACK-based instruccional design model in a technology integration course. Educ. Technol. Res. Dev. 2014, 62, 437-460. [CrossRef]

32. Cabero, J.; Barroso, J. ICT teacher traingin: A view of the TPACK model/Formación del profesorado en TIC: Una vision del TPACK. Cult. Y. Educ. 2016, 28, 633-663. [CrossRef]

(C) 2019 by the authors. Licensee MDPI, Basel, Switzerland. This article is an open access article distributed under the terms and conditions of the Creative Commons Attribution (CC BY) license (http:// creativecommons.org/licenses/by/4.0/). 